Article

\title{
Evaluation of Fruit and Vegetable Containers Made from Mulberry Wood (Morus Alba L.) Waste
}

\author{
Manuel Ferrandez-Villena *(D), Clara Eugenia Ferrandez-Garcia, Teresa Garcia-Ortuño, \\ Antonio Ferrandez-Garcia and Maria Teresa Ferrandez-Garcia \\ Department. of Engineering; Universidad Miguel Hernández, 03300 Orihuela, Spain; \\ cferrandez@umh.es (C.E.F.-G.); tgarcia@umh.es (T.G.-O.); antonio.ferrandezg@umh.es (A.F.-G.); \\ mt.ferrandez@umh.es; (M.T.F.-G.) \\ * Correspondence: m.ferrandez@umh.es; Tel.: +34-966-749-716
}

Received: 14 February 2019; Accepted: 25 April 2019; Published: 30 April 2019

check for updates

\begin{abstract}
Mulberry trees (Morus alba L.) are used as ornamental and shade trees in urban gardening in Spain. These trees must be pruned once a year, and the waste is usually sent to the tip. Current research efforts aim to optimize biomass-based material sources and reduce the pressure on natural and planted forests. The objective of this study was to produce fruit and vegetable containers using particleboards made from mulberry tree pruning waste and to evaluate their properties. Mulberry particleboards were made and their mechanical properties were tested to demonstrate their suitability for industrial uses. Afterwards, the containers made with mulberry particleboards were tested. The strength of the containers was less than $5000 \mathrm{~kg}$ to dynamic compressive strength. Deformation by stacking was $3.15 \mathrm{~mm}$, which is less than the maximum allowed of $6.1 \mathrm{~mm}$, and flexural deformation of the base was $2 \mathrm{~mm}$.
\end{abstract}

Keywords: particleboards; containers; mechanical properties; waste recovery

\section{Introduction}

Mulberry is a widely cultivated tree in Asian countries. It is a fast-growing, deep-rooted, deciduous, perennial tree. Mulberry leaves are the only available food for the silkworm Bombyx mori L. [1]. Additionally, mulberry can be used for animal forage, fruit, medicine, paper, gas production, gardening, firewood, timber and as protection against wildfires in dry areas [2].

Historically, mulberry has been used effectively in traditional Asian medicine to treat various infectious and internal diseases. There are many studies on the structural characteristics and bioactivities of mulberry polysaccharides that support their therapeutic potential and beneficial properties [3], and their main bioactive components have been analyzed, including anthocyanins, polysaccharides, phenols, alkaloids and flavonoids [4]. Research has also analyzed the structural characteristics of the polysaccharides in their branches [5,6], polyphenols have been obtained from the bark and used to whiten cosmetics [7], and among the many bio-functional components of mulberry, 1-deoxynojirimycin has been successfully used in clinical therapy to reduce blood sugar levels [8,9].

Currently, there are numerous studies about the use of mulberry as animal feed [10]. Through treatments with mulberry polysaccharides, the weight of chickens has been increased, improving the animals' immune activity [11]. This result has also been achieved with pigs [12,13].

Traditionally, mulberry wood has been well considered in cabinetmaking due to its good quality. Several studies have shown that it is resistant to both termites and fungi [14-16] and that it has good structural [17] and dynamic [18] properties. According to the European Commission's Horizon 2020 programme, the expected wood deficit in the EU is estimated to be 448 million $\mathrm{m}^{3}$. In this regard, a project has been carried out in eastern Spain to promote mulberry as a substitute material to help alleviate the aforementioned shortage [19]. 
Mulberry wood is used to manufacture barrels, especially for the production of balsamic vinegar (from Modena or Jerez), since the last fermentation takes place in them to obtain suitable properties and qualities [20]. The wine's contact with the wood during the fermentation and ageing processes produces significant changes in its chemical composition and organoleptic properties, modifying its final quality. In this regard, studies have been developed on mulberry barrels for oenology, defining the extractable composition of each type of barrel and their use in wine production [21].

In Spain, sericulture was abandoned in the 1970s; hence, mulberry trees are currently cultivated as ornamental and shading trees in urban gardening. These trees are pruned at least once a year. This pruning results in a white-yellowish wood, which is either sent to landfill or burned. Currently, the trend is to improve these waste management practices and use waste to make new products. The lignocellulosic waste from the urban pruning of mulberry trees used in the ornamental vegetation of Mediterranean countries has been quantified. The mean quantity of dried pruned biomass obtained in street and park locations was $31.67 \mathrm{~kg} /$ tree and $77.78 \mathrm{~kg} /$ tree [22].

There are studies on the use of mulberry pruning waste from urban forests as an energy source [23]. Morus alba L. pruning waste had suitable values of chemical and physical properties for use in soilless substrates [24]. The composting of mulberry pruning waste and wastewater sludge together is beneficial for soil improvement and vegetation growth as compared to their use separately [25]. Using waste wood for the production of wood-based materials has been considered environmentally sustainable, economically viable and socially acceptable. Each year a huge amount of biomass results from the seasonal pruning of woody tree species through agricultural practice and plantations in gardens and streets, which could be a cheap, adequate resource [26]. Attempts have been made to reduce the use of wood in particleboard by introducing mixtures of forest waste [27], whole trees [28], gardening tree pruning [26,29] and fruit tree pruning [30]. Particleboards have been designed with mulberry pruning waste using different adhesives: phenol formaldehyde [31], urea formaldehyde [32] and starches [33]. In addition, mulberry laminated veneer lumbers with different impregnation products for construction materials have been investigated as fire retardants [34].

Fresh fruit and vegetable containers are a very important part of transport logistics from producer to consumer. Part of the product losses is due to bruising caused by poor handling and low-quality packaging. Adequate packaging can reduce squashing and bruising of products, improve sales, reduce moisture loss, reduce contamination and spoilage, reduce theft and maintain a clean environment during the sale of the products [35]. Fresh fruit containers measure $300 \times 200 \times 112 \mathrm{~mm}$ and are made from plywood, as stipulated in the Spanish standard [36]. Substituting timber products with pruning waste (due to wood scarcity) and avoiding burning waste has environmental benefits.

Previous studies conducted on particleboards made with mulberry pruning waste have shown good results [32]. Other studies have been conducted on containers made with Arundo donax L. [37], which performed similarly to conventional wood containers.

The objective of this research was to make fruit and vegetable containers using mulberry pruning waste particleboards, analyze their mechanical properties and evaluate their industrial applications.

\section{Materials and Methods}

\subsection{Raw Materials}

The material used was one-year-old mulberry (Morus alba L.) branches obtained from tree pruning operations. These branches were taken from shaping and pruning operations carried out in the gardens of Universidad Miguel Hernandez in Orihuela, Alicante (Spain). The branches had a diameter of $<2 \mathrm{~cm}$, as can be seen in Figure 1. The initial moisture content of the branches was $87 \%$. The branches were placed vertically to air dry for 12 months to reach a moisture content of $7.8 \%$.

The static bending resistance ( $\mathrm{fm}$ ), the modulus of elasticity $(\mathrm{Em})$ and the density of the mulberry branches were measured using 10 specimens from the thickest and the thinnest end. 
The branches were then cut into pieces measuring approximately $5-10 \mathrm{~cm}$ long, they were shredded in a blade mill. The particle sizes used were 0.25 to $1 \mathrm{~mm}$.

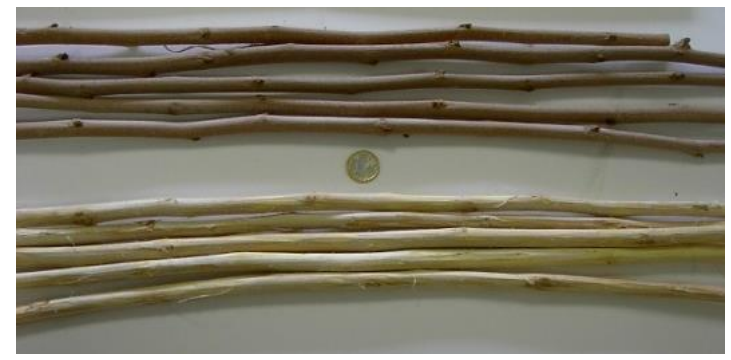

Figure 1. Mulberry branches obtained from pruning operations.

The morphology of the internal structure of the raw material was evaluated using a scanning electron microscope (SEM), and an elemental analysis (quantitative and semi-quantitative) was conducted using energy-dispersive X-ray spectroscopy (EDS). Pictures were taken of fractured cross sections measuring $5 \times 5 \mathrm{~mm}$. For the observation, a microscope (Hitachi S3000N) equipped with an X-ray detector (Briuke XFlash 3001) was used.

As a binder $8 \%$ urea formaldehyde (UF) class E1 was used based on the dry weight of the Morus alba L. particles. Ammonium nitrate at a concentration of $0.4 \%$ (based on the weight of oven-dry particles) was used as a hardener. The solids content of UF was $60 \%$.

\subsection{Particleboard Sample Manufacturing and Testing}

Fourteen particleboards were manufactured (four for testing the boards and ten for constructing the containers) by resin addition in accordance with the standard industrial dry process. The pressure used was $2.6 \mathrm{MPa}$, and the temperature was $120^{\circ} \mathrm{C}$ for $6 \mathrm{~min}$. No waxes or hydrophobic substances were used. They were single-layer boards and their dimensions were $600 \times 400 \times 3 \mathrm{~mm}$.

The mechanical and physical properties determined were: moisture content [38], density [39], the modulus of rupture (MOR) and modulus of elasticity (MOE) [40], internal bonding strength (IB) [41], screw holding strength (SH) [42], water absorption (WA) and thickness swelling (TS) [43].

For the tests, the wood particleboards were cut to obtain samples with the dimensions indicated in the European standards from each of them: six rectangular samples with a width of $50 \mathrm{~mm}$ (three for each direction) were used to test the modulus of rupture (MOR) and modulus of elasticity (MOE), three samples measuring $50 \times 50 \mathrm{~mm}$ were used to test the internal bonding strength (IB), three rectangular samples weighing $10 \mathrm{~g}$ were used for the moisture content test, six samples were used to evaluate the density, three samples were used to evaluate water absorption (WA) and thickness swelling (TS) after immersion in water for 2 and $24 \mathrm{~h}$, and three samples measuring $70 \times 70 \mathrm{~mm}$ were used to determine screw holding strength (SH).

Before performing the tests, the samples were placed in a conservation chamber for $24 \mathrm{~h}$ at a temperature of $20{ }^{\circ} \mathrm{C}$ and at $65 \%$ relative humidity.

The moisture content was measured in an Imal laboratory moisture meter (model 200). For the water immersion test, a heated reservoir was used, with a water temperature of $20^{\circ} \mathrm{C}$. The mechanical properties were tested using a universal Imal testing machine (Model IB600). The conservation chamber used is from JP Selecta (Medilow-L model). The tests were carried out in the construction laboratory of the Orihuela School of Engineering (Universidad Miguel Hernández) at a temperature of $20{ }^{\circ} \mathrm{C}$ and at $65 \%$ relative humidity.

\subsection{Container Manufacturing}

The boards were then cut into pieces, as shown in Figure 2, to make the containers, which were simple boxes measuring $300 \times 200 \times 112 \mathrm{~mm}$ in accordance with the standard [36]. The board parts 
were stapled to each other and to solid pine wood corners to form the container, as shown in Figure 2 . The pine corners gave the containers the necessary strength to be stacked into piles. This kind of container is generally used for single journeys and can hold between 2.5 and $3 \mathrm{~kg}$ of fruit.

Eighteen containers were made and their mechanical strength to compression and stacking was tested under transport simulation conditions.

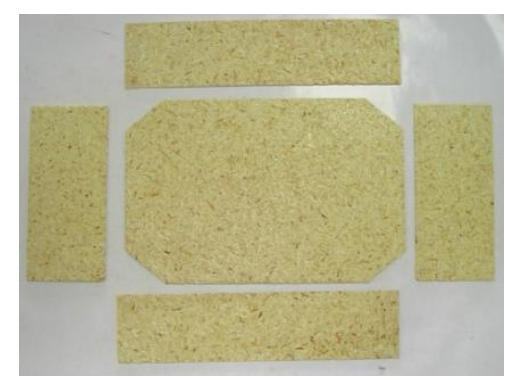

(a)

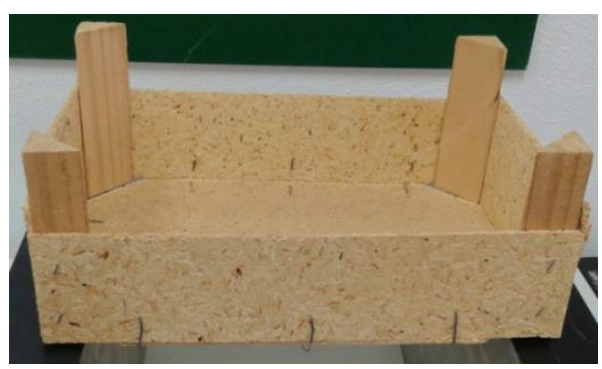

(b)

Figure 2. (a) Board pieces, (b) container type.

\subsection{Container Testing}

Tests were conducted in accordance with Spanish and European standards. The flexural strength of the base of the container [44] is tested by placing a load (S) inside the container, which must be calculated using formula (1). Then the deformation of the base is measured at the center of the board.

$$
\mathrm{S}=(\mathrm{P} / 2)+\mathrm{P}
$$

where $P$ is the weight of the full container.

The static flexural strength of the base [45] was tested in six containers. The test consisted of placing a load (S) into each container and measuring the deformation at the center of the base after 10 min.

Stacking tests evaluate the container's resistance during the storage phase. Two containers were placed one on top of the other on a horizontal surface and tested under compression in the universal testing machine. For this test, six containers were used, stacked in pairs. A total of three compression strength tests were conducted. Method 3 of the standard was used and the applied load (C) was calculated using the following formula:

$$
\mathrm{C}=\mathrm{M} \cdot(\mathrm{H}-1) \cdot 1.5
$$

where

$\mathrm{M}=$ Weight of the stacked containers

$\mathrm{H}=$ Number of stacked containers

$1.5=$ Safety factor

The dynamic compressive strength [46] test was carried out by measuring the maximum compressive deformation that the containers resisted. This test was conducted in six containers. The load application speed was $10 \mathrm{~mm} / \mathrm{min} \pm 3 \mathrm{~mm} / \mathrm{min}$. For this kind of container, the standard requires $\geq 3500 \mathrm{~kg}$.

The containers were evaluated in accordance with the standard [47].

\subsection{Statistical Analysis}

Statistical analyses were conducted using IBM, SPSS v. 25.0. software (V.25, IBM, Armonk, New York, NY, USA, 2018). The mean value and standard deviation were reported for each value. 


\section{Results and Discussion}

The results of the flexion and density values of the mulberry branches compared to the woods used to make the plywood boards for packaging are shown in Table 1.

Table 1. Properties of mulberry wood, Scots pine, poplar and eucalyptus.

\begin{tabular}{|c|c|c|c|c|}
\hline Wood & $\begin{array}{l}\text { Density } \\
\left(\mathrm{kg} / \mathrm{m}^{3}\right)\end{array}$ & $\begin{array}{c}\mathrm{Fm} \\
\left(\mathrm{N} / \mathrm{cm}^{2}\right)\end{array}$ & $\begin{array}{c}\text { Em } \\
\left(\mathrm{N} / \mathrm{cm}^{2}\right)\end{array}$ & References \\
\hline Mulberry branches with bark & $445-630$ & $27-40$ & 550-1300 & This study \\
\hline Pinus sylvestris & $478-570$ & $28-61$ & $8700-11,598$ & [48] \\
\hline Poplar & 378 & 6.1 & 700 & [49] \\
\hline Eucalyptus & 790 & 14.1 & 1655 & [49] \\
\hline
\end{tabular}

Em. static bending modulus, fm: Static bending resistance.

A great variability of properties is observed in the mulberry branches, depending on the part of the branch where the measurements are made, observing a high $\mathrm{fm}$, similar to that of the Scots pine and an Em similar to fast-growing cultivated woods. Scots pine also shows great variations, depending on the area of Spain where it has grown, and it presents a high degree of rigidity.

The scanning electron microscope (SEM) image in Figure 3a corresponds to a tangential section of a one-year-old mulberry branch. The longitudinal fibers can be seen, surrounded by small holes. The energy-dispersive $X$-ray spectroscopy (EDS) results shown in Figure $3 \mathrm{~b}$ indicates that the particles do not contain harmful metals or minerals that can contaminate food products; hence, its use as a food container is suitable.

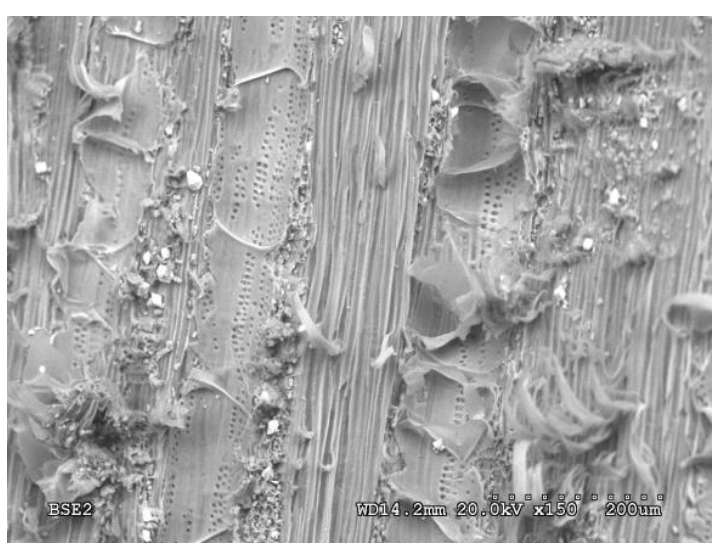

(a)

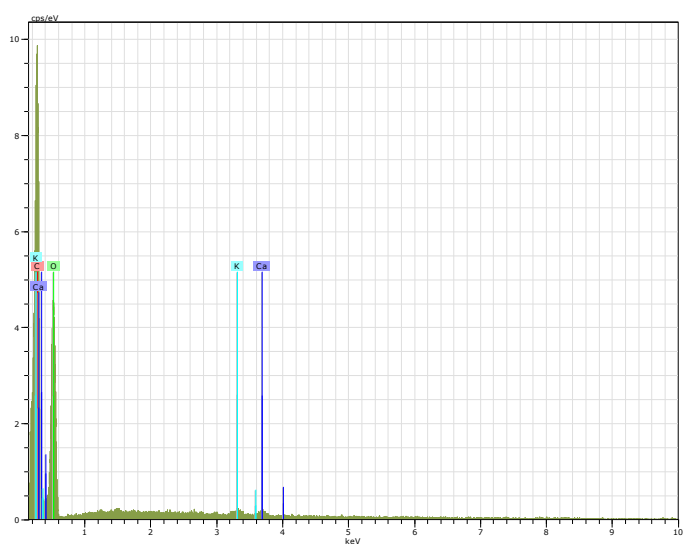

(b)

Figure 3. (a) Scanning electron microscope (SEM) image, (b) energy-dispersive X-ray spectroscopy (EDS) analysis.

The results of the physical and mechanical tests conducted on the mulberry pruning waste particleboards are shown in Table 2. Conventional plywood boards were also tested as control samples, the results of which are also shown in Table 2.

Mulberry particleboards are almost twice as dense as conventional plywood boards. The moisture content of the particleboards was $2.5 \%$, which is less than wood and conventional plywood. This value is in accordance with the standard, which requires a moisture content of less than $20 \%$.

The MOR and MOE values are lower than for conventional plywood boards. The higher density and lower mechanical performance of mulberry particleboards make these boards of lower quality than those usually used to make this kind of containers. 
Table 2. Physical properties of mulberry and conventional plywood.

\begin{tabular}{|c|c|c|c|c|c|}
\hline Particleboard Type & Thickness (mm) & Density $\left(\mathrm{kg} / \mathrm{m}^{3}\right)$ & Moisture Content (\%) & TS (24 h) (\%) & WA $(24 \mathrm{~h})(\%)$ \\
\hline Mulberry pruning waste particleboard & $3.10(0.42)$ & $853.86(33.92)$ & $2.5(0.6)$ & $21.4(2.3)$ & $50.9(3.6)$ \\
\hline Conventional plywood & $2.95(0.03)$ & $457.57(7.20)$ & $5.39(0.2)$ & $6.3(1.2)$ & $86.5(6.5)$ \\
\hline
\end{tabular}

TS: Thickness swelling; WA: Water absorption. RH: Moisture content of the boards. Data in parentheses: standard deviation.

As seen in Table 2, the moisture content of mulberry boards is half that found in plywood boards, which can be considered an advantage. It is also observed that the TS (24 h) is greater than that of plywood, but it meets the requirements for type P3 boards [50] and can be used in humid environments because it is less than $25 \%$. The results obtained for WA after $24 \mathrm{~h}$ are significantly better than those obtained for plywood. Finally, it can be seen that the mulberry boards have worse physical qualities than plywood since they have twice the density and the thickness swelling\% is almost triple, although the water they absorb is similar.

In Table 3, it can be seen that the modulus of rupture in flexion (MOR) and modulus of elasticity (MOE) values are lower in the mulberry boards than in the commercial plywood boards.

Table 3. Properties of the mulberry and industrial plywood boards.

\begin{tabular}{|c|c|c|c|c|}
\hline Board Type & $\begin{array}{c}\text { MOR } \\
\left(\mathrm{N} / \mathrm{mm}^{2}\right)\end{array}$ & $\begin{array}{c}\text { MOE } \\
\left(\mathrm{N} / \mathrm{mm}^{2}\right)\end{array}$ & $\begin{array}{c}\text { IB } \\
\left(\mathrm{N} / \mathrm{mm}^{2}\right)\end{array}$ & $\begin{array}{c}\mathrm{SH} \\
(\mathrm{N} / \mathrm{mm})\end{array}$ \\
\hline Agglomerate pruning mulberry & $20.51(2.62)$ & $1906.70(327.46)$ & $1.65(0.45)$ & $68.36(5.83)$ \\
\hline Industrial plywood & $63.04(12.40)$ & $6853.04(1,924.1)$ & $0.73(0.2)$ & $21.11(1.58)$ \\
\hline P3 requirements & 13 & 1800 & 0.50 & 0.8 \\
\hline
\end{tabular}

Requirements for interior-grade type (including furniture), according to the EN 312 standard. MOR: Modulus of Rupture in flexion; MOE: Modulus of Elasticity; IB: Internal bonding; SH: Screw holding strength. Data in parentheses: standard deviation.

According to the European standard (36), mulberry boards would be type P3: non-structural boards usable in humid environments.

Compared to industrial plywood, these boards have much higher internal bonding and screw holding strength, although their flexural strength is significantly lower.

In Table 3, it can be seen that, due to the higher density of mulberry particleboards, the average weight of the containers was $0.418 \mathrm{~kg}$, around $32.7 \%$ higher than conventional containers, whose average weight is around $0.315 \mathrm{~kg}$.

The flexural strength of the container's base was tested considering a full weight of $2.5 \mathrm{~kg}$. Therefore, the full container weight $(\mathrm{P})$ is $2.5+0.418=2.918 \mathrm{~kg}$.

The weight (S) according to formula (1) is $\mathrm{S}=4.377 \mathrm{~kg}$.

Plastic balls full of water (each weighing $200 \mathrm{~g}$ ) were placed inside the container to reach a weight of $4.40 \mathrm{~kg}$, as can be seen in Figure $4 \mathrm{a}$.

Six containers were tested, and the results obtained are shown in Table 4.

Table 4. Flexural strength of the base.

\begin{tabular}{cc}
\hline Container No. & Deformation (mm) \\
\hline 1 & 1.71 \\
2 & 2.11 \\
3 & 2.14 \\
4 & 1.77 \\
5 & 2.10 \\
6 & 2.10 \\
mean & $2.00(0.23)$ \\
\hline
\end{tabular}

( ) Standard deviation. 


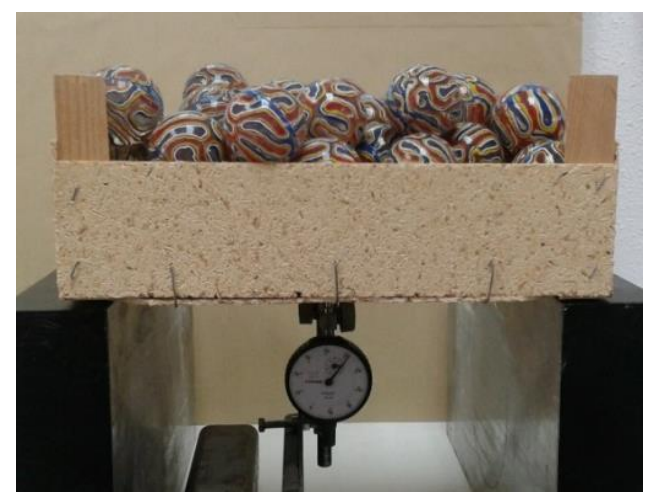

(a)

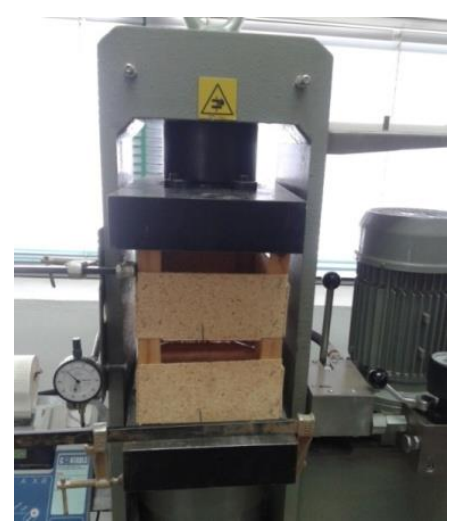

(b)

Figure 4. (a) Flexural strength test of the container's base; (b) stacking test.

According to the standard, base deformation must be $\leq 2 \mathrm{~mm}$. Therefore, the mean base deformation of $2.00 \pm 0.23 \mathrm{~mm}$ of mulberry pruning waste particleboards would indicate that the flexural strength value of their base is on the limit of being useful to the industry. However, we have to consider that the test was conducted using a $4.4 \mathrm{~kg}$ load instead of $4.377 \mathrm{~kg}$, which was the exact value according to the standard.

The stacking test was conducted on six containers. Two containers were stacked as shown in Figure $4 \mathrm{~b}$ and loaded with a force " $\mathrm{C}$ ", which is obtained by the formula:

$$
C=(0.418 \times 2) \cdot(2-1) \cdot 1.5=1254 \mathrm{~N} .
$$

A load " $\mathrm{C}$ " of $1660 \mathrm{~N}$ was applied and the values obtained are shown in Table 5. The compressive deformation limit established by the standard is $5 \%$ of the container's height. In this test, a value of $1.4 \%$ was obtained, which indicates that the containers meet the requirements of the stacking standard.

Table 5. Stacking test results.

\begin{tabular}{cccc}
\hline Container No. & “C” Load (N) & Deformation $(\mathbf{m m})$ & Deformation/Height (\%) \\
\hline $7-8$ & 1660 & 3.80 & 1.69 \\
$9-10$ & 1660 & 3.20 & 1.43 \\
$11-12$ & 1660 & 2.45 & 1.09 \\
mean & 1660 & $3.15(0.65)$ & $1.40(0.30)$ \\
\hline
\end{tabular}

( ): Standard deviation.

Dynamic compressive strength tests were conducted on six containers. A dynamic load was applied to failure. The test results are shown in Table 6. A large standard deviation was observed between the values. This could be due to the fact that some containers were made with the external part of the particleboards, which had lower resistance values.

According to the standard, the dynamic compressive strength should be $\geq 3500 \mathrm{~kg} \approx 34,300 \mathrm{~N}$. Hence, the mean value of $19,500 \mathrm{~N}$ obtained indicates that these containers do not meet the requirements of the standard.

During this test, the containers did not fail, but the testing machine stopped the test because the staples that joined the particleboards to the solid pine corners detached from the solid pine corners and the containers came apart. This may indicate that the $8 \mathrm{~mm}$ crown staples used were not suitable for this kind of containers; therefore, it would be of interest to study alternative joining methods or staples with a greater crown width. 
Table 6. Dynamic compressive strength results.

\begin{tabular}{ccc}
\hline Container No. & Dynamic Load (N) & Deformation (mm) \\
\hline 13 & 20,500 & 4.36 \\
14 & 19,500 & 5.18 \\
15 & 20,500 & 6.32 \\
16 & 20,500 & 4.56 \\
17 & 17,000 & 5.68 \\
18 & 19,000 & 4.22 \\
mean & $19,500(1378)$ & $5.05(0.83)$ \\
\hline
\end{tabular}

( ): Standard deviation.

The study [38] conducted on the use of Arundo donax L. to produce fruit and vegetable containers showed that it was possible to obtain a container that met all the criteria of the standards. These containers were lighter and showed higher mechanical strength. This may suggest that it could be of interest to study containers made with mulberry particleboards that have a lower density and weight. In previous studies [32], it can be observed that stronger mulberry boards were obtained with a higher temperature and smaller particle sizes. Therefore, it would be necessary to attempt to produce boards with a smaller particle size and pressure and a higher temperature in order to lower the density. The boards in this research were produced at a temperature of $120^{\circ} \mathrm{C}$ and industrial boards are manufactured at $180-220^{\circ} \mathrm{C}$. Therefore, the temperature could be increased without significantly increasing the energy cost.

The percentage of UF used was similar to that used in a previous work [38], where it was observed that this type of adhesive did not negatively affect stored strawberries and tomatoes. However, further studies are needed.

Studies have identified extractive products as possible toxic elements of mulberry wood, which are directly related to allergic reactions detected among the makers of mulberry wood musical instruments [16]. These reactions appear to have resulted from direct handling of the wood by craftsmen and its manipulation in poorly ventilated places. This aspect has been taken into consideration in this research when crushing the mulberry branches, taking care that this is done in open places and with closed tanks, as they are manufactured industrially. Mulberry wood has been used for many years in the manufacture of barrels to make a balsamic vinegar, so it can be presumed that the use of mulberry wood in horticultural containers is perfectly compatible.

The municipal authorities invest a large number of resources in the pruning and removal of mulberry waste [23]. The trunks are used as firewood, but the branches are sent directly to landfill. Due to the large amount of bark they have, the branches generate high concentrations of ash, which obstructs the burners [51]. The use of waste wood for the production of wood-based materials has been considered environmentally sustainable, economically viable and socially acceptable [52], especially considering that the cost of managing mulberry branches in an authorized landfill is $€ 18 / \mathrm{m}^{3}$ in southeast Spain. The profitability of using mulberry pruning resources is conditioned by the amount of biomass in the ecosystems of urban communities. If there is abundant residual biomass, as is the case in eastern Spain, it is possible to achieve both ecologically and energetically profitable objectives [22].

\section{Conclusions}

Mulberry particleboards were too heavy, with a mean weight of $0.418 \mathrm{~kg}$, compared to conventional particleboards, which weigh around $0.315 \mathrm{~kg}$. The mean density and thickness were higher than the plywood boards conventionally used to make fruit and vegetable containers; hence, it is necessary to reduce these values.

The containers met the requirements for flexural deformation of the base and stacking tests. However, they did not meet the requirements for dynamic compressive strength due to the staples detaching. 
Mulberry pruning-waste particleboards could be a good alternative material to produce containers if the appropriate thickness, density and joining system are selected.

A large amount of mulberry pruning waste is generated from urban gardens. Utilizing this waste would have both economic and environmental benefits.

Author Contributions: M.T.F.-G. and C.E.F.-G. devised and designed the experiments; M.F.-V. and T.G.-O. performed the experiments; A.F.-G. and M.T.F.-G. analyzed the data; M.F.-V. contributed reagents/materials/analysis tools; M.T.F.-G. wrote the first draft of the paper. All authors assisted in writing and improving the paper.

Funding: This research was funded by the Spanish Ministry of Economy, Industry and Competitiveness through the "Retos" programme, project AGL2013-41612-R.

Acknowledgments: The authors wish to acknowledge the support of the Spanish Ministry of Economy, Industry and Competitiveness through the "Retos" programme, project AGL2013-41612-R.

Conflicts of Interest: The authors declare no conflict of interest.

\section{References}

1. Ghandhi Doss, S.; Chakraborti, S.P.; Roychowdhuri, S.; Das, N.K.; Vijayan, K.; Ghosh, P.D. Development of mulberry varieties for sustainable growth and leaf yield in temperate and subtropical regions of India. Euphytica 2012, 185, 215-225. [CrossRef]

2. Harizanis, P.C. Manual of Sericulture; Ministry of Agricultural Development and Food, Directorate of Animal Production: Athens, Greece, 2007; p. 26.

3. He, X.; Fang, J.; Ruan, Y.; Wang, X.; Sun, Y.; Wu, N.; Huang, L. Structures, bioactivities and future prospective of polysaccharides from Morus alba (white mulberry): A review. Food Chem. 2018, 245, 899-910. [CrossRef]

4. Wen, P.; Hu, T.G.; Linhardt, R.J.; Liao, S.T.; Wu, H.; Zou, Y.X. Mulberry: A review of bioactive compounds and advanced processing technology. Trends Food Sci. Technol. 2019, 83, 138-158. [CrossRef]

5. Chen, Z.; Du, X.; Yang, Y.; Cui, X.; Zhang, Z.; Li, Y. Comparative study of chemical composition and active components against $\alpha$-glucosidase of various medicinal parts of Morus alba L. Biomed. Chromatogr. 2018, 32, e4328. [CrossRef]

6. Qiu, F.; He, T.Z.; Zhang, Y.Q. The isolation and the characterization of two polysaccharides from the branch bark of mulberry (Morus alba L.). Arch. Pharmacal Res. 2016, 39, 887-896. [CrossRef]

7. Wang, S.; Liu, X.M.; Zhang, J.; Zhang, Y.Q. An efficient preparation of Mulberroside A from the branch bark of mulberry and its effect on the inhibition oftyrosinase activity. PLoS ONE 2014, 9, 109396-109407. [CrossRef]

8. Chen, W.; Liang, T.; Zuo, W.; Wu, X.; Shen, Z.; Wang, F.; Peng, G. Neuroprotective effect of 1-Deoxynojirimycin on cognitive impairment, $\beta$-amyloid deposition, and neuroinflammation in the SAMP8 mice. Biomed. Pharmacother. 2018, 106, 92-97. [CrossRef]

9. Guo, C.; Li, R.; Zheng, N.; Xu, L.; Liang, T.; He, Q. Anti-diabetic effect of ramulus mori polysaccharides, isolated from Morus alba L., on STZ-diabetic mice through blocking inflammatory response and attenuating oxidative stress. Int. Immunopharmacol. 2013, 16, 93-99. [CrossRef]

10. Sánchez, M.D. World distribution and utilization of Mulberry and its potential for animal feeding. Anim. Prod. Health Paper 2002, 147, 1-8.

11. Chen, X.; Sheng, Z.; Qiu, S.; Yang, H.; Jia, J.; Wang, J.; Jiang, C. Purification, characterization and in vitro and in vivo immune enhancement of polysaccharides from mulberry leaves. PLoS ONE 2019, 14, e0208611. [CrossRef]

12. Zhu, Z.E.; Jiang, J.J.; Jie, J.J.; Mao, X.B.; Bing, Y.U.; Chen, D.W. Effect of dietary supplementation with mulberry (Morus alba L.) leaves on the growth performance, meat quality and antioxidative capacity of finishing pigs. J. Integr. Agric. 2019, 18, 143-151. [CrossRef]

13. Serpunja, S.; Sankar, K.; Kim, J.K.; Kim, I.H. Impacts of dietary $\beta$-glucan (Morus Alba and Curcuma longa) supplementation on growth performance, apparent total tract digestibility, fecal microbial, fecal characteristics, and blood profiles in weanling pigs. J. Appl. Anim. Res. 2018, 46, 1509-1515. [CrossRef]

14. Mansour, M.M.; Salem, M.Z.M.; Khamis, M.H.; Ali, H.M. Natural durability of Citharexylum spinosum and Morus alba woods against three mold fungi. BioResources 2015, 10, 5330-5344. [CrossRef] 
15. Hassan, B.; Ahmed, S.; Mehmood, N.; Mankowski, M.E.; Misbah-ul-Haq, M. Toxicity potential of heartwood extractives from two mulberry species against Heterotermes indicola. Maderas Ciencia Tecnología $2019,21$. [CrossRef]

16. Golpayegani, A.S.; Thevenon, M.F.; Gril, J.; Masson, E.; Pourtahmasiç, K. Toxicity potential in the extraneous compounds of white mulbery wood (Morus alba). Maderas Ciencia Tecnología 2014, 16, 227-238. [CrossRef]

17. Gündüz, G.; Yıldırım, N.; Şirin, G.; Onat, S.M. Some anatomical, chemical, physical and mechanic properties of white mulberry (Morus alba L.) Tree. J. For. 2009, 5, 131-149.

18. Golpayegani, A.S.; Brémaud, I.; Gril, J.; Thevenon, M.F.; Arnould, O.; Pourtahmasi, K. Effect of extractions on dynamic mechanical properties of white mulberry (Morus alba). J. Wood Sci. 2012, 58, 153-162. [CrossRef]

19. Proyecto PO07-040. FEDER 80\%. Caracterización de Recursos Fitogenéticos de Morera (Morus alba) y Desarrollo de Aprovechamientos para su Revalorización; IMIDA: Murcia, Spain, 2014.

20. Vivas, N. Manual de Tonelería: Destinado a Usuarios de Toneles; Mundi-Prensa Libros: Madrid, Spain, 2005; p. 231, ISBN 9788484762058.

21. Martinez-Gil, A.; del Alamo-Sanza, M.; Sánchez-Gómez, R.; Nevares, I. Different Woods in Cooperage for Oenology: A Review. Beverages 2018, 4, 94. [CrossRef]

22. Velázquez-Martí, B.; Sajdak, M.; López-Cortés, I. Available residual biomass obtained from pruning Morus alba L. trees cultivated in urban forest. Renew. Energy 2013, 60, 27-33. [CrossRef]

23. Velazquez-Marti, B.; Sajdak, M.; Lopez-Cortes, I.; Callejón-Ferre, A.J. Wood characterization for energy application proceeding from pruning Morus alba L., Platanus hispanica Munchh. and Sophora japonica L. in urban areas. Renew. Energy 2014, 62, 478-483. [CrossRef]

24. Moral, R.; Bustamante, M.; Ferrández-García, C.E.; Andréu-Rodríguez, J.; Ferrández-García, M.T.; Garcia-Ortuño, T. New Biomass Sources to Reduce Peat Dependence in Mediterranean Substrates: Validation of Morus alba L., Sorghum vulgare L., and Phoenix canariensis Pruning Wastes. Commun. Soil Sci. Plant Anal. 2015, 46 (Suppl. 1), 10-19. [CrossRef]

25. Si, L.; Peng, X.; Zhou, J. The suitability of growing mulberry (Morus alba L.) on soils consisting of urban sludge composted with garden waste: A new method for urban sludge disposal. Environ. Sci. Pollut. Res. 2019, 26, 1379-1393. [CrossRef]

26. Nasser, R.A. Physical and mechanical properties of three-layer particleboard manufactured from the tree pruning of seven wood species. World Appl. Sci. J. 2012, 19, 741-753. [CrossRef]

27. Turgut Sahin, H.; Burak Arslan, M. Weathering performance of particleboards manufactured from blends of forest residues with Red pine (Pinus brutia) wood. Maderas Ciencia Tecnología 2011, 13, 337-346. [CrossRef]

28. Hiziroglu, S.; Holcomb, R. Some of the properties of three-layer particleboard made from eastern redcedar. Build. Environ. 2005, 40, 719-723. [CrossRef]

29. Duarte da Silva, M.J.; Bezerra, B.S.; Gomes Battistelle, R.A.; De Domenico Valareli, I. Prospects for the use of municipal tree pruning wastes in particleboard production. Waste Manag. Res. 2013, 31, 960-965. [CrossRef] [PubMed]

30. Lykidis, C.; Grigoriou, A.; Barboutis, I. Utilisation of wood biomass residues from fruit tree branches, evergreen hardwood shrubs and Greek fir wood as raw materials for particleboard production. Part A. Mechanical properties. Wood Mater. Sci. Eng. 2014, 9, 202-208. [CrossRef]

31. Yu, H.X.; Fang, C.R.; Xu, M.P.; Guo, F.Y.; Yu, W.J. Effects of density and resin content on the physical and mechanical properties of scrimber manufactured from mulberry branches. J. Wood Sci. 2015, 61, 159-164. [CrossRef]

32. Ferrández-García, C.E.; García-Ortuño, T.; Andreu-Rodríguez, J.; Ferrández-Villena, M.; Ferrández-García, M.T. Manufacture and properties of particleboard made from mulberry pruning waste. In Structures and Environmental Technologies, Proceedings of the International Conference of Agricultural Engineering-CIGR-AgEng 2012: Agriculture and engineering for a Healthier Life, Valencia, Spain, 8-12 July 2012; CIGR-EurAgEng: East Lansing, MI, USA, 2012; pp. 468-473, ISBN 84-615-9654-4.

33. García-Ortuño, T.; Ferrández-Villena, M.; Ferrández-García, M.T.; Andréu-Rodríguez, J.; Ferrández-García, C.E. Properties of particleboards made from mulberry bonded with different natural adhesives. In Proceedings of the VII Iberian Congress of Agroengineering and Horticultural Sciences, Madrid, Spain, 26-29 August 2013; ISBN 978-84-695-9055-3.

34. Kurt, Ș.; Uysal, B. Combustion properties of mulberry (Morus alba L.) laminated veneer lumbers bonded with PVAC, PF adhesives and impregnated with some fire-retardants. Wood Res. 2010, 55, 99-114. [CrossRef] 
35. Schuur, C.C.M. Packaging for Fruits, Vegetables and Root Crops; FAO, Representative Office in Barbados: Rome, Italy, 1988.

36. UNE 49051. Packaging-Wood Packaging for Fruit and Vegetables. Base of $300 \times 200 \mathrm{~mm}$; Asociación Española de Normalización y Certificación: Madrid, Spain, 2002.

37. García-Ortuño, T.; Carbonell-Barrachina, A.A.; Andréu-Rodríguez, J.; Ferrández-García, M.T.; Calín-Sánchez, A.; Ferrández-Villena, M.; Ferrández-García, C.E. Turning waste into a resource: Study of the effect of containers made of giant reed weeds on the shelf life and quality of tomatoes and strawberries. Cien. Inv. Agr. 2013, 40, 149-159. [CrossRef]

38. EN 322. Wood-Based Panels. Determination of Moisture Content; European Committee for Standardization: Brussels, Belgium, 1993.

39. EN 323. Wood-Based Panels. Determination of Density; European Committee for Standardization: Brussels, Belgium, 1993.

40. EN 310. Wood-Based Panels. Determination of Modulus of Elasticity in Bending and of Bending Strength; European Committee for Standardization: Brussels, Belgium, 1993.

41. EN 319. Particleboards and Fiberboards. Determination of Tensile Strength Perpendicular to the Plane of De Board; European Committee for Standardization: Brussels, Belgium, 1993.

42. EN 320. Particleboards and Fibreboards-Determination of Resistance to Axial Withdrawal of Screw; Committee for Standardization: Brussels, Belgium, 2011.

43. EN 317. Particleboards and Fiberboards. Determination of Swelling in Thickness after Immersion in Water; European Committee for Standardization: Brussels, Belgium, 1993.

44. UNE 49706. Packaging-Packaging for the Transport of Fruit and Vegetables. Determination of the Static Deflection of the Bottom; Asociación Española de Normalización y Certificación: Madrid, Spain, 2002.

45. EN ISO 12048. Packaging-Complete, Filled Transport Packages-Compression and Stacking Tests Using a Compression Tester (ISO 12048:1994); ISO: Geneve, Switzerland, 2001.

46. EN ISO 2234. Packaging-Complete, Filled Transport Packages and Unit Loads-Stacking Tests Using a Static Load (ISO 2234:2000); ISO: Geneve, Switzerland, 2003.

47. EN ISO 2233. Packaging-Complete, Filled Transport Packages and Unit Loads. Conditioning for Testing (ISO 2233:2000); ISO: Geneve, Switzerland, 2002.

48. Hermoso, E.; Fernández-Golfín, J.I.; Díez, R. Madera estructural de pino silvestre: Caracterización mecánica. For. Syst. 2002, 11, 425-440.

49. Fernández-Golfín, J.I.; Oliva, A.G.; Merino, M.B.; Barra, M.D. Características físico-mecánicas de las maderas de especies de crecimiento rápido de procedencia española. For. Syst. 1995, 4, 251-261.

50. EN 312. Particleboards-Specifications; European Committee for Standardization: Brussels, Belgium, 2010.

51. Hays, M.D.; Fine, P.M.; Geron, C.D.; Kleeman, M.J.; Gullett, B.K. Open burning of agricultural biomass: Physical and chemical properties of particle-phase emissions. Atmos. Environ. 2005, 39, 6747-6764. [CrossRef]

52. Feng, S.; Cheng, S.; Yuan, Z.; Leitch, M.; Xu, C.C. Valorization of bark for chemicals and materials: A review. Renew. Sustain. Energy Rev. 2013, 26, 560-578. [CrossRef]

(C) 2019 by the authors. Licensee MDPI, Basel, Switzerland. This article is an open access article distributed under the terms and conditions of the Creative Commons Attribution (CC BY) license (http://creativecommons.org/licenses/by/4.0/). 